\section{Strawberry Species of Iturup and Sakhalin Islands}

\author{
Kim E. Hummer ${ }^{1}$ \\ USDA-ARS, NCGR, 33447 Peoria Road, Corvallis, OR 97333-2521
}

Andrey Sabitov
VIR, Far East Experiment Station, Vavilov Str. 9 Vladivostok 690025, Russia

Additional index words. Fragaria iinumae, Fragaria nipponica, Fragaria yezoensis, Fragaria iturupensis, genetic resources, germplasm

\begin{abstract}
A plant-collecting expedition to Iturup and Sakhalin Islands, Sakhalin Territory, Russian Federation, occurred between 21 July and 12 Sept. 2003. Strawberries, Fragaria $L$., were observed and collected. Japanese and Russian flora describe two diploid $(2 n=2 x=14)$ species, $F$. iinumae Makino and the Yezoensis strawberry, $F$. nipponica Makino [syn. = Fragaria nipponica var. yezoensis (H. Hara) Kitam.], as native to those islands. In addition, a recent monograph described a new octoploid $(2 n=8 x=56)$ strawberry species, $\boldsymbol{F}$. iturupensis Staudt, from a Japanese herbarium specimen collected on Atsunupuri volcano near Lesozovodoskyi, Iturup, in 1929. The objectives of the 2003 collecting trip were to obtain wild strawberries from these islands and determine if a population of $F$. iturupensis still existed on the volcano. The native $F$. iinumae Makino was obtained from the Ogonki Village, Anivskyi Region, Southern Sakhalin Island, but was not observed on Iturup. The Yezoensis strawberry was observed at Cape Otlivnoy, Iturup. Two small colonies of the native octoploid $\boldsymbol{F}$. iturupensis Staudt were collected from mid-elevations on the east-facing slope of Atsunupuri volcano. The native distribution of $F$. iturupensis was limited to this volcanic montane habitat and was not found in the foggy, sandy locations of coastal elevations on Iturup. The leaf morphology and growth habit of $F$. iturupensis plants were similar to that of $F$. virginiana subsp. glauca (S. Watson) Staudt of North America, but the fruit was different, more like $F$. vesca $\mathrm{L}$. Probable cultivated escapes were observed at two sites on the east coast of Iturup and at one site in southern Sakhalin. The 2003 expedition confirmed the existence of $F$. iturupensis, the only known native Asian octoploid strawberry on Atsunupuri. Limited quantities of germplasm are available for research from the curator, U.S. Department of Agriculture, Agricultural Research Service, National Clonal Germplasm Repository, Corvallis, OR, the U.S. national strawberry gene bank.
\end{abstract}

Staudt (1973) determined that a plant originally collected by a Japanese botanist from Atsunupuri volcano on Iturup Island was an octoploid species that he named $F$. iturupensis. The distribution of this species was reported to be only from this locality. Examples of this species were unavailable in the 1990s and early 2000s for further research. Conjecture by American, Japanese, and Russian botanists called for confirmation of the existence of this, the only Asian octoploid, and determination of how this species fits into Fragaria phylogeny. Scientists also wondered if additional distributions of this species could be found on Sakhalin or other nearby islands.

Iturup Island is the second island to the northeast of Hokkaido and is the largest island of the Greater Kurile Archipelago. It is $\approx 100 \mathrm{~km} \times 25 \mathrm{~km}$ with a northeast-

Received for publication 31 Mar. 2008. Accepted for publication 3 May 2008.

We acknowledge funding for this project from USDA ARS CRIS 5358-21000-033-00D and a USDA, ARS Plant Exploration Grant for 2003.

${ }^{1}$ To whom reprint requests should be addressed; e-mail Kim.Hummer@ars.usda.gov southwest alignment. The Greater Kurile Islands extend northeastward from Hokkaido to the Kamchatka Peninsula. These islands separate the Sea of Okhotsk from the Pacific Ocean.

Sakhalin is a long, narrow island $\approx 1000 \times$ $200 \mathrm{~km}$ with a north-south longitudinal alignment situated at its closest point $\approx 6$ $\mathrm{km}$ east of the Asian continent. The formation of the Kurile Archipelago began in the late Cretaceous $(\approx 90$ million years before the present) when the Okhotsk Terrain of the Kula Plate collided with the Siberian continent (Kimura and Tamaki, 1985) creating a subduction zone along the southeast margin of the Okhotsk Terrain. Iturup and other islands of the Greater Kurile Ridge began to form during the late Oligocene and Miocene, and the volcanic activity that gave rise to this Ridge is still in progress (McKenna, 1983). The northern Kuriles are recently formed and are developing their flora, receiving plant migrations from Kamchatka at their north and from Japan through the southern Kuriles (Miyabe, 1890).

Iturup has been above sea level since the early Pliocene. During the glacial sea-level regressions of the late Pleistocene, Iturup, Kunashir, and the islands of the Lesser Kurile
Ridge may have been connected with each other and with Hokkaido. Glaciers covered the northern and central Kurile Islands during the glacial maximum of the Pleistocene but probably did not extend any further south than central Iturup, because no trace of glaciations has been observed on Kunashir or in the Lesser Kurile Islands (Kryvolutskaya, 1973). This suggests that parts of southern Iturup may have provided a refugia for ancient plant species.

The human population of Iturup is mainly comprised of military personnel and fishermen. The island is difficult to access by boat or plane as a result of weather conditions and political constraints. Only a few scientific expeditions have visited the island during the past decade.

The flora of this region is preboreal, and indigenous island genera have related species in Western Europe and North America (Charkevicz, 1996). Charkevicz (1996) described only two diploid Fragaria species native to the far eastern island region of Russia: F. iinumae and F. nipponica. Both of these species are native to Sakhalin and the Kurile Islands. In the Flora of Japan, Ohwi (1965) presents $F$. iinumae and separated $F$. nipponica from $F$. yezoensis with the key character difference of ascending versus spreading hairs. More recent Japanese floristic treatments have submerged $F$. yezoensis within $F$. nipponica (Naruhashi and Iwata, 1988). This species association is under additional botanical scrutiny (Staudt, personal communication). Fragaria vesca L. is a European introduction into this region (Ohwi, 1965) and is not native to Sakhalin, Hokkaido, or the Kurile Islands. Staudt (1973, 1989) studied a Japanese herbarium specimen and seedlings of strawberries from Iturup Island. The specimen proved to be octoploid $(2 n=8 x=56)$ and he named the species $F$. iturupensis Staudt. This is the only known native Asian octoploid species.

The objective of this project was to obtain strawberry samples from Iturup and Sakhalin Islands and to determine if the strawberries growing on Atsunupuri volcano could be verified as the octoploid $F$. iturupensis.

\section{Materials and Methods}

From 27 July to 11 Aug. 2003, a plantcollecting expedition was made to Iturup and Sakhalin Islands, Russian Federation. This trip occurred through scientific collaboration between the U.S. Department of Agriculture and the N. I. Vavilov All-Union Research Institute, Russian Federation. On 29 July 2003, the expedition flew from Korsakovo, Sakhalin Island, to Burevestnik, Iturup Island. Because there are no roads, the islands were traversed on foot or with some assistance from military vehicles. Three days of hiking were needed to reach Atsunupuri volcano from Burevestnik. During this expedition, more than 145 clonal and seed samples of berries were collected representing six genera and 21 species. The collection localities and dates for Fragaria species that were encountered are presented (Table 1). 
Table 1. Collection information for strawberries, Fragaria L., collected on Iturup and Sakhalin Islands, Russian Federation, in $2003^{z}$.

\begin{tabular}{|c|c|c|c|c|c|}
\hline Collection date & Collection no. & Corvallis no. & Species & Ploidy & Locality \\
\hline 16 Aug. & $37-\mathrm{OG}$ & 1842 & F. iinumae Makino & Diploid & $\begin{array}{l}\text { Sakhalin Island, Anivskii Region, } 16 \text { km from } \\
\text { Ogon'ki Village by Ogonki-Gornozavodsk Road; } \\
\text { elevation } 123 \mathrm{~m} ; 46^{\circ} 42^{\prime} 492^{\prime \prime} \mathrm{N}, 142^{\circ} 13 \sim 483^{\prime \prime} \mathrm{E}\end{array}$ \\
\hline 30 July & $38-\mathrm{KH}$ & 1838 & F. $\times$ ananassa escape & Octoploid & $\begin{array}{l}\text { Iturup Island, near the road from Shumi-Gorodok } \\
\text { Village to the bridge over the Khvoynaya River; } \\
44.8190^{\circ} \mathrm{N}, 147.5503^{\circ} \mathrm{E}\end{array}$ \\
\hline 3 Aug. & 40-OTC & 1840 & F. nipponica Makino & Diploid & $\begin{array}{l}\text { Iturup Island, Eastern (Pacific) Coast on Cape } \\
\text { Otlivnoy } 15 \mathrm{~km} \text { south of Shumi-Gorodok Village; } \\
44.9276^{\circ} \mathrm{N}, 147.5766^{\circ} \mathrm{E}\end{array}$ \\
\hline 5 Aug. & 41-ATS & 1843 & F. iturupensis Staudt & Octoploid & $\begin{array}{l}\text { Iturup Island, on eastern slope of Atsonupuri volcano; } \\
\text { elevation } 630 \mathrm{~m} ; 45^{\circ} 06^{\prime} 748^{\prime \prime} \mathrm{N}, 147^{\circ} 58^{\prime} 796^{\prime \prime} \mathrm{E}\end{array}$ \\
\hline
\end{tabular}

Ploidy is based on root tip chromosome counts and flow cytometry.

Strawberry runners and fruits were gathered from the wild in their native locations on Sakhalin and Iturup Islands. An open population sample of as many fruit as were available from each strawberry colony was collected. The seeds were extracted from the fruit at camp near the collection sites. Runner plants and seeds were brought to the Far East Experiment Station, Vladivostok, Russia. Portions of the seeds of each seedlot were sent to the U.S. strawberry gene bank in Corvallis, OR, where representative seedlings were grown.

Chromosome counts were performed on $F$. iturupensis samples in Corvallis on cells from actively growing root tips. Samples were pretreated in $0.002 \mathrm{M} 8$-hydroxyquinoline, fixed in Farmer's solution (absolute ethanol and glacial acetic acid at 3:1 ratio), rinsed, and stored in $70 \%$ ethanol. Samples were stained in acetocarmine (Smith, 1947) and chromosomes were counted. Flow cytometry was also performed on mature summer leaves of each of the collected Asian species in Aug. 2007 (Plant Cytometry Services, Schijndel, The Netherlands) as another estimate of ploidy.

\section{Results}

Strawberry specimens were collected from five locations on Iturup Island, three near sea level and two growing in higher elevations on Atsunupuri volcano. Two samples of strawberry were collected on Sakhalin Island (Table 1).

Fragaria iinumae. On Sakhalin, these plants were collected from the edge of a forest road, $7 \mathrm{~km}$ southwest of Ogon'ki Village. Salix spp. and Sasa kurilesis Makino et Shibata were growing nearby. The strawberries were semiprostrate, perennial herbs 7 to $15 \mathrm{~cm}$ tall.

Fragaria nipponica (Yezoensis strawberry). Fruit from a large colony of $F$. nipponica was collected on Cape Otlivnoy. This colony was growing in coastal sand at $\approx 3 \mathrm{~m}$ elevation. The plants grew in dense grass and shrubs in association with Convallaria keiskei Miq., Lilium dahuricum KerGawl, Lothyrus maritimus Bigll., Geranium erianthum D.C., Sasa kurilensis Makino et Shibata, Equisetum silvaticum L., Pinus pumula Rgl., Sorbus sambucifolia Roem., Larix curilensis Mayr., and Rosa rugosa Thunb.

Fragaria iturupensis. The plants grew on pumice scree of the eastern slope of Atsunupuri volcano. The leaf and plant morphology of this species agreed with Staudt (1973) as similar to $F$. virginiana subsp. glauca (S. Watson) Staudt of North America. Fruit and plant specimens were obtained from two small populations at elevations of 630 and $650 \mathrm{~m}$ (Fig. 1). Only a few nonflowering single plants were seen on the lower part of the stone slope. Plants occurred mostly on the border of the dwarfed forest edge. Associated plants included Alnus maximowiczii Call., Salix fumosa Turcz., Artemesia borealis Pall., A. arctica Less., and Carex micropoda C.A. Mey.

The fruit dimensions were $\approx 1.5 \times 1.6 \mathrm{~cm}$ with a maximum weight of $1.5 \mathrm{~g} / \mathrm{berry}$. Chromosome counts from cells of actively dividing seedling root tips indicated that the plants were octoploid $(2 n=2 x=56)$, which agrees with Staudt et al. (2008).

Escaped octoploid species. At Goryachie Kluchi Village and on the left side of the road

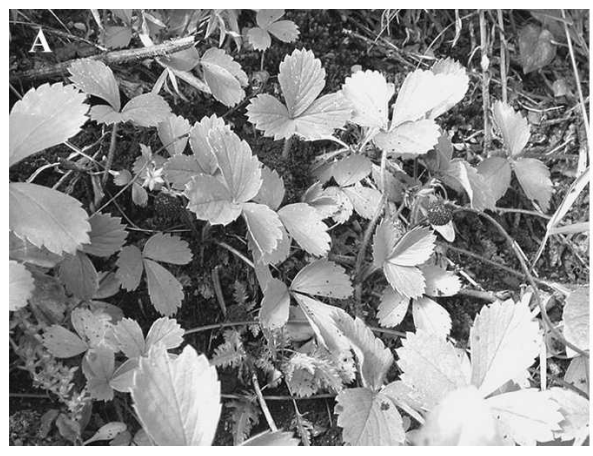

\section{B}

Fig. 1. Fragaria iturupensis Staudt plant (A) and fruit (B) from Atsunupuri volcano, Iturup Island, Russian Federation.

from Shumi-Gorodok Village to the KhvoyUjno-Sakhalinsk City near the Sanitarium called "Mountain Air", Sakhalin, we collected three samples of larger fruited strawberries, probably $F$. Xananassa, from plants having morphological characters that did not match descriptions for native species. Fruit set was poor. Fruit were irregularly shaped and not fully mature. The maximum weight was $4.4 \mathrm{~g} /$ berry.

\section{Discussion and Conclusions}

Fragaria iinumae was found on southern Sakhalin Island and the Yezoensis strawberry was found on Iturup. These observations agree with distribution maps for these species in the Russian and Japanese flora (Charkevicz, 1996; Ohwi, 1965).

The Iturup strawberry, $F$. iturupensis, has limited distribution on the Atsunupuri volcano but is octoploid. Further analyses of the genomes of these Asian species are in progress. The origin of the North American octoploid species remains unknown, but Staudt (1999) postulated that "a hypothetical octoploid species probably arose in East Asia and may have migrated via an AlaskanSiberian land bridge to North America".

With seedlings provided from this exploration, Staudt et al. (2008) contrasted pollen

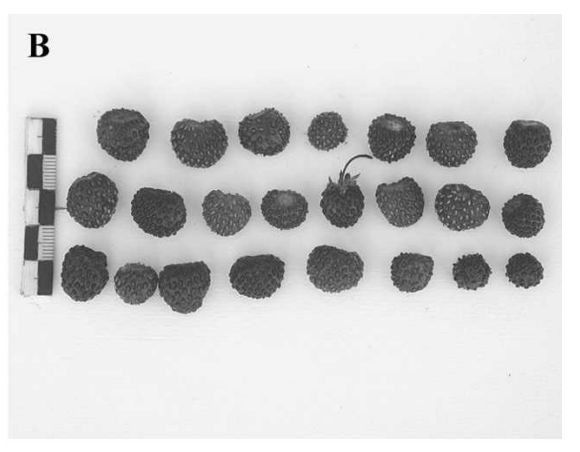
naya River, Iturup, and on the outskirts of 
grain morphology, aroma, and flavor components in the Iturup strawberry fruit with those of North American octoploid species $F$. virginiana and $F$. chiloensis. The phenological relationship of the hermaphroditic Iturup strawberry seems further differentiated than that of these heteroecious octoploid species than originally postulated (Staudt et al., 2008). The quest for an ancestral link between lower ploidy Asian strawberries and North American octoploids continues.

Our 2003 plant-collecting expedition confirmed the existence of $F$. iturupensis, the only known native Asian octoploid strawberry, on the east side of Atsunupuri volcano, Iturup Island: $F$. iinumae on Sakhalin and the Yezoensis strawberry on Iturup. In addition, escaped octoploid strawberries were observed on both islands. Limited quantities of seeds or plant germplasm of these strawberries are available for research by request to the author at the U.S. Department of
Agriculture Corvallis gene bank. Future exploration on Kunishir and other nearby islands is planned.

\section{Literature Cited}

Charkevicz, S.S. 1996. Fragaria L. Plantae Vasculares Orientis extremi Sovietici. Tomus. Vol. 8. p. 163-165 [in Russian].

Kimura, G. and K. Tamaki. 1985. Tectonic framework of the Kuril Arc since its initiation, p. 641-676. In: Nasu, N., K. Kobayashi, S Uyeda, I. Kushiro, and H. Kagami (eds.). Formation of active ocean margins. Terra Scientific Publishing Co., Tokyo, Japan.

Kryvolutskaya, G.O. 1973. Entomofauna of the Kurile Islands: Principal features and origin. Izdatelstvo Nauka, Leningrad, Russia.

McKenna, M.C. 1983. Holarctic landmass rearrangement, cosmic events, and cenozoic terrestrial organisms. Ann. Mo. Bot. Gard. 70:459-489

Miyabe, K. 1890. The flora of the Kurile Islands. Memoirs of the Boston Society of Natural History. Vol. IV, No. VII. p. 203-275.
Naruhashi, N. and T. Iwata. 1988. Taxonomic reevaluation of Fragaria nipponica Makino and allied species. J. Phytogeography and Taxonomy 36:59-64.

Ohwi, J. 1965. Flora of Japan [in English]. Smithsonian Inst., Washington, DC. p. 523 524.

Smith, L. 1947. The acetocarmine smear technique. Stain. Tech 22:17-26.

Staudt, G. 1973. 1973. Fragaria iturupensis, eine neue Erdbeerart aus Ostasien [Fragaria iturupensis, a new strawberry species from East Asia]. Willdenowia 7:101-104.

Staudt, G. 1989. The species of Fragaria, their taxonomy and geographical distribution. Acta Hort. 265:23-33.

Staudt, G. 1999. Systematics and geographical distribution of the american strawberry species. University of California Press-Berkeley. Botany. 81:139-151.

Staudt, G., S. Schneider, P. Scheewe, D. Ulrich, and K. Olbricht. 2008. Fragaria iturupensis, a new source for strawberry improvement? Proc. of the VI International Strawberry Symposium, Huelva, Spain. p. 49. Abst. 887. 